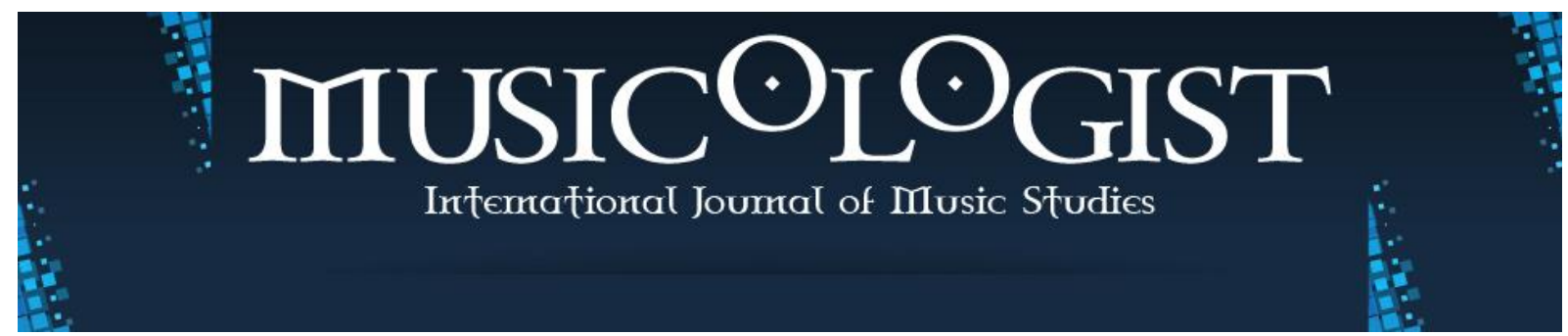

Trabzon University State Conservatory @ 2017-2020

Volume 4 Issue 1 June 2020

Research Article

Musicologist 2020. 4 (1): 1-33

DOI: $10.33906 /$ musicologist.712316

\author{
FEDERICA NARDELLA \\ King's College, London \\ federica.nardella@kcl.ac.uk \\ orcid.org/0000-0001-5014-0886
}

\title{
The Late Ottoman Şarkı and the Interweaving of Registers: Towards an Ideology of Song
}

\begin{abstract}
This paper investigates the şarkı song form, composed in the late nineteenth century, discussed with regards to the linguistic registers that characterised the use of Turkish in the same period1. It considers the production and circulation of this popular vocal repertoire in relation to reforms in language education and an intense, public conversation about the place of Turkish in a society on the verge of a controversial modernity. My aim has been to suggest new ways of thinking about the role of song in supporting or subverting - and occasionally, both - language practice and efforts at standardisation, as well as considering it in the more general framework of language debate. The material chosen is a small group of songs appeared in the newspaper Ma'lûmât in December 1895. By particularly focusing on the way that various registers interweave in the texts, I have suggested that we look at this repertoire as a reflection of wider linguistic/cultural tensions. While Ottomanperiod Turkish has often been regarded as an unreadable, impenetrable language belonging to the elites, the case of the şarkı and its urban, newspaper reading public suggests that we should begin looking at it as a language spectrum encapsulating a multitude of registers, chosen according to the intended meaning and occasion. I propose to consider song in its capacity to maintain affections and authority, as well as providing a tool for self-mapping in history and tradition. In the late Ottoman scenario, this translates into reconsidering notions of cultural and social schisms in favour of a fluidity in both language and music practice, that is manifest in the şarkı text.
\end{abstract}

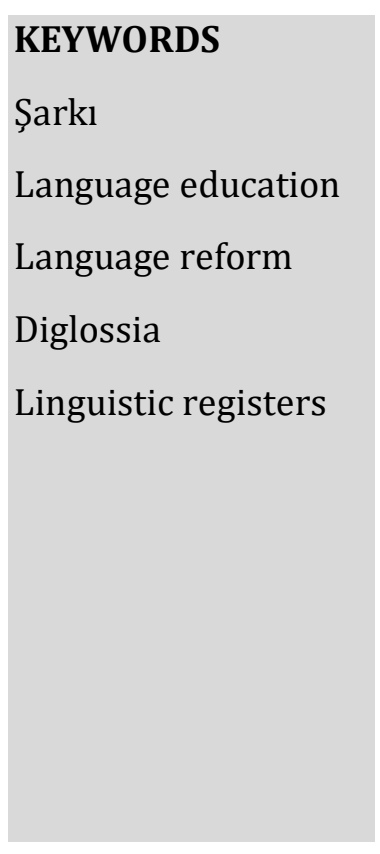

1 The term Ottoman Turkish, conventionally employed to describe the language used in pre-Republican Turkey, is - as will be seen in the paper - a controversial one. A first draft of this paper referred to the language by using that term but after some reflection and valuable suggestions, I have decided to substitute it with an expression that may convey more precisely the sense of fluidity I am discussing here. The main idea is that there is one language, Turkish, existing in different registers or modes, if you wish, and that the Turkish used prior to the foundation of the Turkish Republic (1923) is operating at a different mode from the one used today but should still be considered Turkish. The reasons for this decision will become apparent in the course of my discussion. I thank here Hikmet Toker for the discussion and suggestions provided on this particular topic. My gratitude also goes to Martin Stokes and Katherine Butler Schofield for their advice.

Received: March 31, 2020; Accepted: May 07, 2020 
The second half of the Ottoman nineteenth century was a time of complex linguistic debate and intense efforts at standardization. From pedagogical reforms to the first works of linguistics, between the mid-nineteenth and early twentieth centuries, the Ottoman language issue became the arena in which ethnic and religious identities were affirmed, rejected, re-elaborated, and established. Similar dynamics were at play in central Europe and elsewhere (see De Mauro, 1991; Myhill, 2006; Benes, 2008; Kamusella, 2009; Gal 2011, 2015; Daskalov and Marinov, 2013; Bergeron, 2010). While, on one hand, efforts towards language standardisation were visible in the increasing number of published grammars, dictionaries, as well as dictionaries of wrongly used or misspelled words (galatât), the şarkı vocal repertoire composed and published in the same period suggests that the reality of standardisation may have been more complex.

The discussion proposed in this paper is one regarding the role played by song in processes of linguistic debate about standardisation. In particular, I will consider the ways in which the late nineteenth century şarkı vocal repertoire with its lyrics supported or subverted, contributed to establishing, or challenged, the linguistic policies of the period (on the şarkı form, see Öztuna, 1986, 1988; Özalp, 1992; Feldman, 1996; Akdoğu, 1995; Aksoy, 2003; Tohumcu, 2009; Özbilen, Ayangil, 2009; Uzun, Özkan, 2010; Salgar, 2011, 2017). The paper proposes a new way of thinking about the place of song in late Ottoman urban culture and, more generally, of whether it is possible to talk about an ideology of song, with its own agenda, amidst wider political tensions. My primary interest at this stage lies in understanding the way in which the şarkı complicates what we know of late nineteenth century Ottoman linguistic practice. The lyrics I will examine, printed in the newspaper Ma'lûmât, contain a significant variety of registers. The objective will be to reflect on what the overlapping and interlocking of language registers in song reveals about song's agency and interlocking with sociolinguistic practices, particularly in a standardisation and 'simplification' scenario.

The expressions, formulas, compound words, and phrases recurring in the songs would be familiar to a reading public exposed to dîvân poetry, as the imagery often used could be found within this rich tradition (see Andrews, 1985). This would not exclusively be the case for the palace or bureaucratic elites. It would include the readers of publications such as Ma'lûmât (1895-1903), which offered its readers a music supplement with şarkı lyrics and piano arrangements, and Hanımlara Mahsûs Gazete 
(1895-1908), a publication for women where poems in the dîvân style were sometimes published, including poems in the şarkı form (see also Zeren Enis, 2013). This signals a familiarity that the upper-class readers of these publications had with the registers of the classical poetic tradition. The fact that such musical material was printed and circulated in newspapers may suggest that the wider, burgeoning reading public would be exposed to this vocal repertoire, as would professional performers and composers (on reading practices in late nineteenth century Ottoman society see Fortna, 2011; see also Spooner and Hanaway, 2012 for the Persianate world). It also suggests, I believe, that the notation printed both in Ma'lûmât and Hanımlara Mahsûs Gazete would be aimed at a public performing music for leisure, in a home environment, among family (Duben and Behar, 1991: 223).

There is a tendency to view the later nineteenth century as a time when Turkish became gradually simpler and more accessible for a growing reading public, and that the development of press and newspaper made this possible (see Levend, 1960: 82). However, the song repertoire complicates matters. If the repertoire is taken within the context of its own compositional tradition and performance practice - in other words, that of classical music- then the fact that the şarkı at this time did not shy away from the sophisticated language which was under debate would not surprise us. Within its own framework, that of classical poetic and musical production, it is to be expected that the lyrics adhered to a consolidated tradition and followed certain conventions. However, the complicating factor is the juxtaposition of art song and its text, established in a consolidated, classical poetical tradition with the texts becoming accessible through newspapers and, more generally, through emerging reading-consumption practices, amidst simplification debates. I propose that, in fact, the late nineteenth century Ottoman şarkı publications - both in the form of lyrics collections (güfte mecmuaları) and supplements to newspapers such as Ma'lûmât (1895-1903) and Hanimlara Mahsûs Gazete (1895-1908) - complicate established views regarding the simplification of language.

My discussion will particularly focus on registers in relation to reading publics, asking questions regarding whether song, as register, can be thought of as a bridge-gaping force across "arenas of social life" (Gal, 2018: 3). The case of the şarkı is unique in this respect. Its quality as a particularly flexible and dynamic genre comfortable across the 
socio-cultural spectrum, as well as its audiences and environments, make its channelling of poetry and language which move across the same spectrum by means of registers especially significant.

\section{The şarkı as genre and in the press}

As a genre, the şarkl found success across social strata and environments: it was popular both among the palace and city audiences. It gaped, in a way, bridges and arenas. It found acceptance and popularity first at the palace (in the seventeenth century according to some views, and the eighteenth according to others) and became the focus of compositional activity in the nineteenth century (Reinhard et al., 2001; Öztuna, 1986: 50-53; Hall, 1989; Feldman, 1996: 15; Toker, 2016: 197-198). It was the undisputed protagonist of the fasil's transformation and transition from palace to urban entertainment.2 While the fasil, throughout the sixteenth and seventeenth centuries, included genres such as peşrev, kâr, beste, ağır semâ'î, yürük semâ'î, saz semâ'î (see Hall, 1989 and Feldman, 1996), it came to be gradually dominated by the şarkı. In the nineteenth century, different types of fasıl existed,3 although the şarkı gained prominence.

The most common form of the şarkı in the nineteenth and twentieth centuries was a four-verse stanza. The first verse, repeated twice, introduced the melody, establishing the makâm, and it was called zemîn. This was followed by another verse, the nakarât, or refrain, also repeated twice, which would then be followed by a third verse, called the meyân section, sung only once, in which the melody often modulated to a new makâm. This was followed by a repetition of the nakarât section (see Akdoğu, 1995 Günaydın, 2018). There were, however, variations to this template. Ahmed Tohumcu (2009) aptly highlighted in his paper the way the term şarkı transitioned from indicating a specific type of vocal composition with definite characteristics within the framework of the fasll, to indicating, in the twentieth century, all types of popular vocal works regardless of genres and individual characteristics. In his paper, he discussed this process by using the term yozlaşma, or "degeneration". This notion, to me, suggests a conceptual

\footnotetext{
2 The fasl is a suite of instrumental and vocal compositions., divided into classical (geleneksel or an'anevi fasli) and non-classical (sarkı faslı). The latter is still performed and very popular in Turkey. Its structure underwent significant changes in time, and its current format is that of a cycle of brief songs, opened and closed by an instrumental composition (a peşrev at the beginning, and saz semâ'î at the end). See Hall, 1989 and Feldman, 1996 for a history of the suite's evolution over time.

3 I am grateful to Hikmet Toker for pointing this out.
} 
expansion whereby the term came to encompass a range of vocal genres, regardless of its originally specific structural characteristics and the qualities it embodied. In current Turkish language and musical practice, anything that has lyrics and is sung, is a şarkl, despite its genre categorisation as pop, rock, soul, blues, metal etc. And, as Tohumcu observes, all vocal performers nowadays are şarkıcılar (717). The best translation of this term into English would be simply "singers". However, in the nineteenth century, the term şarkı would still be indicative of a specific genre rather than any song, and a precise text format, one that, as has often been the case, replicated a poetic one - the poetry form şarkı. For this reason, I feel it should be established early on that, in the case of the late Ottoman vocal repertoire, using the term 'song' can generate confusion, as there were, in fact, other types of popular vocal compositions, such as the türkü.4 There were, however, significant differences, as well as overlaps between the two genres. Having a brief look at them will help us position the şarkı in discourses about language.

The meter mostly - although not exclusively - used in the şarkl, the 'arûz, employed in classical Arabic and Persian poetry, places it in a precise domain, that of classical poetry, markedly distinct from folk verse. The official literary life of the şarkı is thought to have begun with the dîvân of the celebrated poet Nedîm (1681-1730), who lived at the court of Ahmed III during the so-called Lâle Devri, or Tulip Era (1718-1730). His oeuvre is commonly regarded as innovative work, which brought the folk/poetic forms of türkü and şarkı to the attention of the court, significantly employing Turkish grammar and a rich Turkish vocabulary: Turkish would from now on slowly carve a niche for itself apart from the conventional Arabic and Persian that had long dominated court literary production and intellectual activity (Bombaci, 1956; İz and Menemencioğlu, 1978). In the dîvân of the eighteenth century poet Vahîd-i Mahtûmi, known as a vocal and instrumental performer of both şarkı and türkü, we find a section titled Murabbât ve Şarkıyyat ve Türkmaniyyât ve Gayrihî containing examples of texts written in hece vezni (the metre used for folk song, the türkü): the inclusion of the şarkı in this section would

\footnotetext{
4 Folk song belonging to the halk müziği (folk music) repertoire. Another aspect worthy of notice pertains to terminology. Sarkı is from the Arabic sharqī, meaning 'oriental' while türkü is a Turkish term indicating a local, popular genre. It is interesting to notice how the former term suggests a foreignness, an 'otherness', that would come to characterise much of the political discourse of the early Republic. A period in which, incidentally, the Ottoman art repertoire was heavily debated as, more generally, was the Ottoman heritage. On this see Signell, 1980; Feldman, 1990-1991; Tekelioğlu, 1996; Stokes, 2010; Erol, 2012; O’Connell, 2013).
} 
seem to indicate that its place in the divvân was among the more popular (stylistically speaking) forms, and thus confirm a greater formal and thematic proximity to the mode of expression of the halk, or the people. However, the great language variety used in the şarkı (ranging from Turkish vocables and syntax to Persian imagery, vocabulary etc.) again places it in a limbo: both sophisticated and popular. The form would be developed both by poets who were also composers, such as Sâmi, Nâbî, and the above-mentioned Nedîm, and composers who would pen their own lyrics.5

As a musical genre and as a poetic form, the şarkl transcended boundaries of class and categories, eventually becoming beloved of both court audiences and urban consumers, professional and amateur musicians. It inhabited and crossed over, as it is often the case with song, the domains of both poetry and music. Despite the fact that it belonged to a classical tradition, it was popular enough to be appreciated in non-court environments, that is to say, centres of popular, urban entertainment, such as taverns (meyhaneler, but not only: see Kalender, 1978), but also gatherings in private houses (see Poulos, 2014), and it was still sophisticated enough not to be eligible to be considered among folk genres. When we talk of 'ideology of song' in the nineteenth century Ottoman context, then, I propose we specifically focus on the peculiarities of the şarkı as both a form and a concept: a form flexible enough to cater for a spectrum of tastes and groups. As I will shortly discuss, I believe the same can be said about Turkish as a language, and as it existed in the centuries before the foundation of the Republic.

In the nineteenth century, the şarkı reached the peak of its popularity (see Tohumcu, 2009). The many collections of song lyrics published in this century give a clear picture in this sense (see Paçacl, 2010; Ekinci, 2015; Yalçın, 2016). Since its earliest appearances, it circulated in a number of mecmû́alar, presumably for private consumption and among amateur or professional musicians of the palace. Its space of consumption, however, gradually expanded as printing practices became widespread (Kunt, 2008; Fortna, 2011) and, more generally, as a consumer culture emerged in urban centres (Frieson, 2000). The development of recording techniques in the late nineteenth/early twentieth century provided an even wider audience to the şarkı

5 Among these we find Hafîz Post, the celebrated Itrî, Nazîm (see Erdemir, 1999). Tanbûri Mustafa Çavuş (1700-1770) was a noted composer of şarkı and so was Sultan Selim III (1762-1808), who reportedly contributed to integrate the form into the fasil (Toker, 2016: 30; for a detailed study of the fasl see Hall, 1989). 
repertoire, in a sense completing the cycle (Ünlü, 2016). Considering the media through which in the late 1800s the şarkı was distributed - newspapers and lyrics books - we can deduce that the form itself began to become, in a way, a commodity. Its appearance in newspapers, for one thing, would suggest the familiarity of a wider public than that of music aficionados and connoisseurs. The case of Hanımalara Mahsûs Gazete suggests the existence of a reading (and playing?) public comprised of women - although not exclusively - from middle and upper class educated families (Zeren Enis, 2013).

\section{The reading public, language education and debate}

The emergence of a mass reading culture is certainly one of the most significant cultural shifts occurring in the nineteenth century. An increasing interest in language pedagogy methods developed alongside, together with ideas regarding language, ethnicity, and ideology. The three phenomena are deeply interrelated. As has been suggested by Levend (1960), the press was a major player in the process of language simplification (dilde sadeleşme) (1960: 82-83), rendering ideas accessible to a wider public. So much so, that he talks about a gazeteci dili (a 'journalist language') and cites Şinasi, the founder of what is considered to be the first Turkish paper, and his intention to make a paper written in a language that everyone would be able to understand available to people (83). The urge for "simplification" seemed both prescriptive and symptomatic of the emergence of the press. The need for simplification presupposes a notion of "difficulty" which is, in truth, an idea that dominated most of the political discourse around language in the twentieth century, and that informed much of the Republican ideology (see Holbrook, 1994; Andrews, Black and Kalpaklı, 2006: 8; Lewis, 1999; Ertürk, 2011). This difficulty was particularly ascribed to the presence of foreign linguistic elements (Arabic and Persian), and much of the debate in the late nineteenth century revolved around what language the Turkish people should use on the basis of its ethnic identity (Levend, 1960; Ertürk, 2011).

As highlighted by Fortna, the growth of a reading public signaled an increase in literacy. The nineteenth century was a time of significant reforms in the field of education. Especially in the era of Abdülhamid II (1876-1909), it became the focus of government policy (Somel, 2010; Vurgun, 2017). Great efforts were spent particularly in the direction of language education, in order for it to reach the villages as much as the disadvantaged parts of urban centres (see Kanal, 2016). Most importantly, emphasis 
was placed on the teaching and learning of "Turkish" as a unifying factor among religious and ethnic communities (again Vurgun, 2017; Somel, 2010; Topuzkanamış, 2018; Şahbaz, 2004; Akaslan, 2018).

The reforms in the field of education interwove with a lively public conversation about the place of Turkish in a multi-ethnic society in transition towards modernity. In very broad terms, at the heart of the language debate lay the concern that the sophisticated Turkish that had existed for centuries as the language of poetry and bureaucracy was unsuitable to an audience operating outside of these two domains (Kushner, 1998). Most importantly, it was a language in which a more national, Turkic spirit could not find identification due to the heavy presence of foreign, unintelligible elements. In the 1890s and generally throughout Abdülhamid's time, the issue of what language should represent the Turkish nation became even more pressing. Linguistics, for one, took a more "nationalistic" turn. In 1893, Necîb 'Âsım's Urâl ve Âltây Lisânları was published. The work is one of the earliest examples of Ottoman linguistics, and one in which ideas regarding language and ethnic identity and affiliation were beginning to be ideologically framed (see Kushner, 1998 [1977]). The work proved an opportunity to discuss the language and its ethnic relations, thus marking clearly a separation between it and the Arabo-Persian world.

By taking a look at the efforts made in the direction of language education, however, it is impossible not to notice a more layered reality, in which children in particular were still taught the three languages and in which, most importantly, various terms for Turkish were used interchangeably.6 This ambivalence points towards an often underestimated aspect: that the chasm between what post-Republic was to be referred to as "Ottoman Turkish" and Turkish was first brought forward as part of the Republican ideology, and has remained perceived as such ever since (see Lewis, 1999). Christine Woodhead, in her chapter "Ottoman Languages" (2011), challenges academic assumptions regarding the state of Turkish in the sixteenth and seventeenth centuries suggesting that the

6 A look at the pedagogic material printed in the second half of the century gives a clear picture: Sarf- 1 Osmânî ('Ottoman Grammar,' by Selîm Sâbit, 1880), Elifbâ-yı Osmânî ('The Ottoman Alphabet,' again by Sâbit 1885/1886), Yeni Usûl Elifbâ-yı Türkî ('New Method for the Turkish Alphabet,' by Şemseddin Sâmî, 1890), the work in four volumes Hâce-i Lisân-ı Osmânî ('Ottoman Language Instructor') with its first volume 'ilm-i Sarf-ı Türkî ('Science of the Grammar of Turkish,' by Manâstırlı Mehmed Rıfat, 1893), and so forth to 1910 (and beyond) with Yeni Usûl Resimli Türk-Osmanlı Elifbâsı Yâhûd Türkçe Dîline Başlângıç ('New Illustrated Method for the Ottoman-Turkish Alphabet, or, Introduction to the Turkish Language,' by Mustafa Fâ'ik). 
seeming divide between more popular and elite Turkish be thought of as varying registers within a "single language spectrum" (146). She points out that, until the nineteenth century, Ottomans referred to their language as "Turkish", seemingly not perceiving the demarcation between higher and lower registers, in either writing or speaking, as so clear-cut (145, also see Strauss, 1995). In her upcoming thesis, Communication $\mathrm{PhD}$ candidate Ester Cristaldi, whom I met in Istanbul, addresses similar questions and, by analysing the language used in late Ottoman/early Republican newspapers, she argues that a relation of continuity existed between mid-nineteenth century Ottoman and early Republican Turkish. She relies on the basic linguistics notion that an institution or organisation can neither change nor dictate a new course for a language. The process is always determined by the speakers of the language. She talks about a language standardization process that began in the $1840 \mathrm{~s}$, with the publication of grammar textbooks for schools. According to her thesis, the process of standardization aimed at unifying varieties of the Turkish language, ranging from more sophisticated to popular. While there is a tendency to speak of diglossia (for an evaluation of the term, see Strauss, 1995) as the linguistic reality of Ottoman society, with sophisticated language on the one, higher end and more basic Turkish for the lower stratum, I resist the notion of diglossia, and suggest that we evaluate şarkı in its capacity to channel the overlapping registers that constitute the essence of Turkish as it was used throughout the centuries since the Ottoman Empire was founded, until the declaration of the Republic. In other words, a fluidity of registers within language rather than two extreme ends of a spectrum (see İz, 1964; Strauss, 1995; Mardin, 2002; Ertürk, 2011; Woodhead, 2011).

As we have seen, the şarkı as a genre itself displayed a fluidity that allowed it to become popular across socio-cultural spaces. The publication of lyrics in newspapers suggests a broadening of the şarkı's audience, in tandem with the widening of a reading public. In his work on the reading culture of the late Ottoman Empire, Fortna points out how the rise of a printing culture could be approached as a phenomenon both consolidating "traditional and intellectual culture" (2011: 17), drawing attention to Ottoman printing and reading practices, "an ongoing attempt to assimilate, supplant and emphasize a number of different cultural bases, including those of the Western European, PersoIslamic and Turkic traditions." (2011: 17) Fortna also highlights how, in the Republican 
era, poetry continued to be present in publications for children, signaling an ongoing "affection" (50) for the heritage that was symptomatic more of continuities between Empire and Republic than a brutal break (30). Indeed, the poetic tradition had always been a staple of Ottoman cultural life, "the highest form of literary expression" (Fortna, 2011: 17, see also Andrews, Black and Kalpakll, 2006). Towards the end of the nineteenth century, poetry increasingly became the medium for nationalist tendencies to be expressed, a shift that, according to Fortna, also signaled a move away from traditional meters (2011: 17). It was at this point, however, that the şarkl - let us not forget, a song and a dîvân poetry form - appeared in the newspapers. I interpret its presence at this very delicate juncture as a sign of both an attachment to a tradition that would carry on into the early days of the Republic, but also as symptomatic of a process of "commercialization" of the Ottoman repertoire. Most importantly, the continuities that Fortna speaks of are, I believe, a key feature of the şarkı's agency in the newspapers. but they should also be considered when looking at language itself. I believe that the şarkı was one of the forms that kept a certain linguistic (and poetic) past present throughout a time of transition and that it did so because, in fact, the language it channelled should not be seen in terms of a schism between higher and lower social spheres but rather, as fluid registers in motion across a spectrum.

If we go back to the differences between and similarities shared by the genre and its "folk" cousin, the türkü, and what the appearance of both in the early collections represented for Turkish as a language in a world dominated by Arabic and Persian, we will immediately become aware of a problem that the genre posed since the very beginning: yes, indeed the linguistic composition changed, with Turkish at the forefront. However, the presence or lack of a specific language depended on the nature and content of the composition itself; it varied from case to case (the same happened with dîvân poetry, see Erdemir, 1999). The phenomenon of mixing registers in poetry had, in fact, always existed and the literary milieu that was not confined to one language:

As one looks at the literature of the whole central Islamic world after Timur (the early fifteenth century) it is even difficult to see a reasonable pattern of literary history that confines itself to the literature of one particular language. Poets easily and regularly transcend languages. A single Ottoman poet might write in Turkish and Persian and Arabic and Eastern Turkic (Chaghatay). (Andrews, Black and Kalpaklı, 2006: 23) 
The reason why I think the şarkı is a genre particularly worthy of consideration when we think about late Ottoman/Turkish language ideology is because, unlike the türkü, it is in this genre that we find this kaleidoscope of registers.

As will be seen from the lyrics that I will present later, the linguistic structure found in the material tells the story of enduring relations and overlapping cultural domains. This overlap, particularly the Perso-Islamic tradition, would be intensely debated and finally in a sense "disposed of" during the Republican era (the Turkish Republic was founded in 1923; see in particular Gökalp, 2017 [1923]). What we find in the 1890s, however, is a repertoire in print and, in fact, flourishing: a repertoire that had a connection both with the world of the court and that of urban audiences.

It is worthwhile thinking about the relationships that such audiences would have with this material. Fortna cites the example of the reading houses (kıraathane), which became increasingly common in the 1890s. These were, to some extent, public places of intellectual debate, where reading newspapers was a core activity. Fortna, in particular, highlights their close links with the publishing industry that made copies of newspapers available for free for their customers (2011: 162). Alongside this public, collective aspect of reading, he also offers a glimpse into the reading world of an individual, the author Halide Nusret (1901-1984). Fortna reports the author's experiences with both learning to read and write first, and becoming a reader and writer later (2011: 193). In the passage reported by Fortna, Nusret recounts the familial intimacy experienced after lunchtime, when she would lie on the bed with her mother and read newspapers such as İkdam, Servet-i Fünûn, Musavver Malûmât and Hanımlara Mahsûs Gazete (194-196). We can infer that, as a musical genre, it participated in the process of becoming public and private readers/writers, while itself originating from the domain of written and recited word (poetry), coming to the attention of a wider public, than that confined within the palace walls. Although Halide Nusret was born in 1901, the language education she received in school (Erenköy Kız Lisesi) would not be different from what children were receiving at the close of the previous century. That is, she would have gone through the process of learning Arabic and Persian too, although she would become a Turkish author, in a linguistic sense. We know from her example that at some point, in her childhood/early adulthood, as part of the publications she would read with her mother, she would have been at least exposed to the şarkı as a printed, musical text 
and to a tradition that, although it would soon become problematic, was an important part of her own literary and linguistic upbringing. It was part of a heritage that nurtured her skills and that a wider reading public was able to enjoy by means of the press. In particular, let us remember the importance of poetry in Ottoman culture and how much it generated - and kept in place - "affection" (Fortna, 2011: 50) towards a contested and yet shared literary repertoire.

\section{Registers and şarkı: the texts}

These reflections partly help us in locating the ideology of song within the emerging language ideology. In particular, we can observe song as a vehicle for tradition and authority in the midst of attempts at, and platforms for, simplification7. Song here caters to all the strata of the language continuum showing how, in fact, these registers had always been integrated and interacting (as the identities they represented; on language performance and identity see Bauman, 1974, 2000; Collins and Blot, 2003; Myhill, 2006; Nic Craith, 2007; Edwards, 2009; Frishkopf, 2013, 2018).

The question of registers was debated on the pages of Ma'lumât - one of the papers in which the songs were published. Tevfik Fikret, founder of the movement Edebiyât-I Cedîde (see note), was one of the contributors to the discussion, together with the famous writer Recâizâde Mahmud Ekrem or others such as Necîb 'Âsım,8 who campaigned in favor of a simpler literary language, based on Turkish. The discussions revolved around which registers were appropriate to use when (Ester Cristaldi, personal communication, February 14, 2019) and in particular the relationship between language and content. This brings us back to the point made by Woodhead, and cited earlier, regarding a language that operated on the basis not of diglossia, rather, of a linguistic flow suiting the occasion. The şarkl emerges as a space where the full spectrum unfolds in a continuum. I would like to suggest that what dominates song and linguistic training in the late 1800s is more an impulse towards balancing strands of

7 The real extent of that simplification is ambivalent as much as the language education and policy of the period. Cristaldi pointed out to me how the articles printed in newspapers displayed themselves a variety of registers, an element that testifies to a reality quite removed from the idea that a homogenous, simplified, newspaper language actually existed. She cited the example of the newspaper Servet-i Fünûn (1891-1944) that had a literary style developed a movement of literati and intellectuals by the name of Edebiyât-ı Cedîde ('New Literature'). They advocated for the use of a sophisticated language in harmony with sophisticated contents and, in particular, for the use of the dîvân language. This was in contrast with other ideas circulating around the same period regarding the need for a simplified, Turkish literary language (Levend, 1960; Kushner, 1998 [1977]).

8 See above for his work on linguistics. 
cultural inflections, the need to sail across a linguistic flux in which registers are not as rigidly bound or defined as we have learned to think. In which yes, language is produced according to the occasion, but in which the occasion itself is produced in the freedom of a vast array of forms.

The songs printed in 1895 display, as expected, considerable variety. The common denominator in the text is always Turkish grammar but the amount of Turkish words used varies according to the piece and the content. However, one important point to bear in mind is that words which come from Arabic and Persian, and which were (and still are) in use in current Turkish, are in fact today perceived as Turkish. The question of whether they were felt to be as such in the late nineteenth century stays open, but my idea is that their origin did not prevent affections and intimacies towards the vocabulary to be formed. This complicates my argument, and it may seem to actually challenge most of the linguistic ideology that animated much of the language reform, in which such terms were considered "foreign". Words such as aşk (from Arabic, expressing a type of "love") have become part of the daily used vocabulary and acquired their own meanings in a Turkish context, which are slightly different from those of its original context. This is a complex issue, but the material we are talking about is essentially a shared vocabulary, thus pointing out its linguistic origins may or may not help depending on the purpose of the analysis. This is an important point: regardless of their origin, a sense of intimacy and affection towards these words existed and continues to exist. The fact that they may be Arabic or Persian in origin is not necessarily known to everyone who uses them. This supports my idea that we need to focus on registers by highlighting the fact that they do not simply exist as foreign elements, but provide a greater liberty of expression through the use of a vast, shared, affection-inspiring vocabulary.

As to the theme, this is generally unrequited love and the impossibility to escape it, as well as incurable attachment to the beloved and lamenting one's black fate. Occasionally, there are songs purely in praise of the beloved's beauty and, in one case, an ode to village life and joys. In the song lyrics, the register used is an integral part of the meaning conveyed. That was also the case for different types of texts produced in 
the late nineteenth century.9 Matching register to meaning and content is functional to the narrative of a text, regardless of the type.10 Registers reflect but also become, in a sense, the subject matter. They suit the occasion produced and produce the occasion. Most importantly, as we will see, the coexistence of different registers in a şarkı - but also within the same book collection of şarkı - displays relationships of authority, influence and affections. In Susan Gal's words, by connecting different "arenas of social action", registers produce interdiscursive connections that "link and organize not only discourses and registers but also societal arrangements" (2018: 1). The interdiscursivity that Gal discusses hinges upon repetition of elements retraceable to specific socio-political contexts but recognizable across those contexts. The repetition of an element traditionally associated with a specific domain not only gives that element an additional layer of meaning, but it actually brings out its socio-political meaning's potential, strengthening agendas and propelling action. She calls the register a "“clasp" or hinge between arenas", regulating relations (3). In the case of the şarkı song-text, for example, the interdiscursivity regulating relations is found in formulas, word compounds, words (see Yahya Kaçar, 2012) that recur throughout the dîvân tradition, connecting the text to a domain of poetic sophistication, but also political authority and power (see Andrews, 1985).

I have chosen twelve songs that appeared in the 5 December 1895 issue.11 In particular, I chose the songs that were included in collections of lyrics (güfte mecmuaları), published throughout the same decade. These are two editions of Sevk-i Dil (1893 and 1894), Ferahfezâ Yâhûd Yeni Şarkı (1896-1897) and Yeni Şarkılar (1896-1897). Moving across this 'repertoire map,' we encounter şarkı that must have been rather popular

\footnotetext{
9 Cristaldi pointed out to me how the register of articles published in papers from 1865 to 1935 exhibited a variety of registers depending on the content of the article.

10 English literature provides an excellent example in Shakespeare's linguistic manipulation in order to reflect the character's internal and interpersonal dynamics: let us think, for example, of the thick, impenetrable language used for Macbeth's thick, impenetrably dark thoughts, or the variety of registers used by different characters in his comedies. In Shakespeare's case, relations are articulated through registers and the registers used by the characters articulate their intents and the way that relations shape their personalities. We have yet another example in Dante's Divina Commedia, where registers additionally map places: hell, purgatory and paradise are depicted through varying registers that range from the lower, vulgar language of Inferno (hell) to the sophisticated, syntactically elaborate, Latininfused language of Paradiso (paradise), via the mild, suffused stillness of the language in the waiting limbo, Purgatorio (purgatory).

11 The paper, held at İBB Atatürk Kitaplığı, is accessible as a PDF file and includes numerous supplements. This led me to think that more than one notation may have been published with each issue, particularly because the same is found with other issues.
} 
throughout the 1890s, although some compositions were included in collections published in previous as well as later decades.12

Let us begin with the texts containing the highest amount of Turkish. I have used different colors to highlight the different languages: red for Turkish, green for Arabic and yellow for Persian. I have highlighted and provided alternatives where I was unsure as to the correct reading, and I left the words in black for words I was unsure of, but also for the name of the makâm, the composer's name and the publication date.

1. Şarkl-yı Hâşim Bey (1895), Usûlü Evfer

Mecbûr oldum ben bir güle

Simdi düştüm dilden dileı13

Firsat bulsam alsam ele

Nakarât

Ben sarılsam ince bele

Sardirmam seni ellere

Nedir cevrin hürrem bana

Bir sözüm var dilber sana

Teşrif eyle bir şeb bana

Eyzân

2. Şarkı-yı Hicâzkâr, Rızâ Efendi (1895)

Düşeyim deriken eyvah vefâlısına

Düştü gönlüm aman ah belâlısına

Doyum olmaz güzelin gerçi edâlısına

Nakarât

Düştü gönlüm aman ah belâlısına

Yoktur cevr ü cefâdır dev belâ çektim ben

12 The songs that appeared as a supplement to Ma'lumât presented the interesting feature of being arranged for piano and having the text transliterated according to French transliteration conventions $(\hat{u}$ transliterated as with the diphthong $o u, \ddot{o}$ as $e u, \hat{\imath}$ as $u i, s$ as $c h$ and so forth). This does not come as a surprise as the newspaper had some sections translated in French (such as the frontpage subtitles) and the supplement itself was called Chant Turc ('Turkish Song'), with French translations of the composer/arranger information, makâm, and rhythmic cycle in French, on the cover. The lyrics appeared after the notation, always with a transliteration. This hints at an expat public or educated, multilingual audience. The prestige attributed to the French language, particularly in the nineteenth century Ottoman urban centres, is well known (see Strauss, 2011 and 2017). It is possible that the şarkl had a foreign audience too and that it was performed by expats or foreign visitors (see Ekinci, 2015 on Madame Herzmainska de Slupno's collection of notations). 13 dil is also Persian. 
Varayım uslanayım vazgeçeyim her şeyden

Başım âsûde güzel sevmeyeyim deriken

Nakarât

Düştü gönlüm aman ah belâlısına14

\section{3. Şarkı-yı Hicâzkâr, Hristo Efendi (1895)}

Gîdelim Göksu'ya bir âlem-i âb eyleyelim

Ol kadehkâr güzeli yâr olarak peyleyelim

Bize bu talimiz oymadı yâr neyleyelim

\section{Nakarât}

Ol kadehkâr güzeli yâr olarak peyleyelim

Yanarak ateş-i aşk içre semendercesine

Cakarak semt-i Kalender'de kalendercesine

Ederek zevk ü safâ hal-ı Sikendercesine

Ol kadehkâr güzeli yar olarak peyleyelim15

4. Şarkı-yı Hüseyni, Rızâ Efendi (1895)

Bak şu güzel köylüye işte bu kızdır peri

Toprak ile oynamış belli güzel elleri

Böyle midir hep aceb köylülerin dilberi

Nakarât

Düştü gönül aşkına terk edemem bu yeri

Köyde imiş anladım mâye-i aşk u hevâ

Dağlara bak sanki aşk olmada suretnümâ

Cuyların nağmesi ruha verir bin safâ

Meskenim olsun benim terk edemem bu yeri

Elde kaval bak çoban eylemedir

Dinlemede hep sürü çünki hazindir kaval

Burda göründü/görendi bana naz ile o gül-ı cemâl

Sevdi gönül neyleyim terk edemem bu yeri

Bak ne güzel söylüyor dalda şu aşık hezâr

Burda bulur bâdesiz neș'eyi her gam küsar

Sen de gönül neş'elen işte budur kuy-i yâr

14 This is the Ferahfezâ version. The Yeni Şarkılar version is a bit different. There is only one stanza and one refrain, and instead of 'ah', that edition has 'Allah'.

15 This is the Ferahfezâ version. The Yeni Şarkılar is different. Again, there is only the first stanza and refrain. 
Ben de anın çün gönül terk edemem bu yeri

Yerde çiçekler bütün handenin âsârıdır Gökte güneş veçhinin makes envârıdır Karșığı orman ise aşkının esrârıdır

Hepsîiseni söylüyor terk edemem bu yeri

Gül yüzünü parlatan ismetinin nûrudur Gönlümü sermest eden mahmurudur Zanıma ol didenin kendi de meșhurudur

Tuttu beni ah o göz terk edemem bu yeri Goncalara kim bakar gül teninin çağıdır Böyle bakan kalbimi gamzesinin dağıdır Saçlarının telleri sanki gönül bağıdır

Gönlümü bend eyledi terk edemem bu yeri

Kalbe safâ serpiyor hep şu bulutlar bugün Başka bir âhenk ile ötmede kuşlar bütün Zann ederim eyliyor burda tabiat

Neş'eye gark oldu dil terk edemem bu yeri

Buy latif veren gonca teni her yere İsvesidir bahşeden derdini aşkın derdini sere Sen de mi sevdâzede söyle mahzundere / dere

Ben de sana benzedim terk edemem bu yeri

\section{5. Şarkı-yı Beyâti, Rızâ Bey (1895)}

Aman ey yar cefâ-pîşe nizâr etme beni Ölürüm sensiz a zâlım bırakıp gitme beni Sitem etme kerem eyle kırıp incitme beni

Nakarât

Ölürüm sensiz a zâlım bırakıp gitme beni

Seni terk etme bana şimdi olmadın da beter Sana qurbân olayım kılma beni mahv vahdır Düşeyim payına çiğne (çeyne) çabucak etme keder

Nakarât

Ölürüm sensiz a zâlım bırakıp gitme beni 
As we can see, most of the texts present a Turkish syntax (verb at the ending of the sentence) as well as vocabulary. The terms in Arabic and Persian are, on the other hand, conventional and recurring throughout dîvân poetry (see Andrews, 1985). They are mostly part of the shared vocabulary of affection that I mentioned earlier. Turkish grammar holds the texts together, beginning and closing each line. In part, the language used corresponds to particular themes. The case of song 3 and 4 is particularly relevant. Song 3 is an invitation to join the narrating voice on a drinking spree in the taverns of Beykoz, particularly the Göksu area. The song refers to other urban locations, such as Kalender, along Istanbul's Bosphorus and refers to familiar dîvân poetry protagonists such as the kadehkâr, the cup-bearer and an ateş-i aşk (fire of love), accompanied by a good dose of zevk ü safâ (pleasure and amusement). Song 4 describes a different, more bucolic, village setting. It does so, predictably, through the prism of love and but it also narrates of an attachment to a place that it is impossible to leave behind, a place where the melancholy voice of the kavâl fills the days spent surrounded by mountains and the mâye-i aşk u hevâ (mâye has more than one meaning, it may refer to the "essence" or "melody," mâye being a type of folk song, "of love and affection"). Against the background of these bucolic joys, the love of the narrator for the güzel köylü ('beautiful villager') blossoms. It is a variation on a familiar theme that is rendered particularly intriguing by the choice of Turkish to describe a non-urban setting where pure love finds its chance for blooming. However, it should be noted that, while Turkish is predominant, Arabic and Persian words are also found, and these are usually used to refer to the beloved (yâr), rosebuds (goncalar) and other floral metaphors for the beloved's beauty, lights (envâr) and secrets of love (aşkının esrârı). These nouns are held together by Turkish syntax and most of them are, in truth, still in use today, symptomatic of the fact that despite their origin, they have become a part of what we call the Turkish language.

Songs 1, 2 and 5 display similar patterns. All of them are so simple in language as to be easily understood by readers today. The Arabic and Persian terminology that they display is more or less still in use, and the lack of the ezâfe, the characteristic Persian particle that links two words together generating compound expressions and providing attributes to nouns, among other functions, is noteworthy.

The songs below contain more Persian and Arabic elements: 


\section{1. Şarkı-yı Hüzzam, Hacı Emin Bey (1895)}

Bir gül-ı ranâye gönül bağladım

Hicri ile tâ beseher ağladım

Kendisinin meyli de var anladım

Nakarât

Aşkını tâ cân evime sakladım

Çeșm-i siyahında dönen cilveler

Kalbimi bin his ile lerzân eder

Vuslatıdır bence hayat değer/hayat-ı dîğer

Nakarât

Aşkını tâ cân evime sakladım

2. Şarkl-yı Uşşâk, Civan Ağa (1895)

Ey dil ne oldun feryât edersin

Feryât u zari mu'tâd edersin

Beyhûde ömrüm berbât edersin

Nakarât

Zannetme yarı münkâd edersin

Yarın cefâsı ta'dâde gelmez

Kuş etmez ehem feryâde gelmez

Bîmürüvvettir imdâde gelmez

Nakarât

Zannetme yarı münkâd edersin

3. Şarkı-yı Muhayyer, Hacı Arif Bey (1895)

Of Of Of Of

Deva yok mu neden bimar-ı aşka

Niçun bir çâre yok nâçâr-ı aşka

Rehâ olmaz mı bend-i nâr-ı așka

Nakarât

Aman ya Rab yandım nâr-ı aşka

Helâk olmaktayım dağ olmadan

Yanar dil zahm-ı dil söz ve sitemden

İlâhî beni kurtar bu gamdan

Nakarât 
4. Şarkı-yı Hicâz, Ali Rıfat Bey (1895)

Hüsn-ı güftarın senin ey mehlikâ

Çeşm-i fetânın gibi sevdâfezâ

Kahkahan cilven gibi șîrîn-edâ

\section{Nakarât}

Tarz-ı reftârın gören dir mehlikâ

Çeşm-i fetânın gibi sevdâfezâ

5. Şarkı-yı Karcığâr ve Şarkı Bestenigâr, Hakkı Bey (1895)

Tezyin ediyor gülşenî şîî ile sünbül

İkmâl ediyor zâr ile bülbül

Sabrım tükenip kalmadı arama tahammül

\section{Nakarât}

Gel seyr edelim canım efendim şa bahârı

Bak mutribe eyler ne güzel beste

Seyre çikmışsın bugün Kağıthaneyi

Eyledin ma'mur dil vîrâne

Miyân

Söz aman söz dide-i mestâneŷ̂

\section{Nakarât}

Eyledin ma'mur dil vîrâneyi

A more complex mixture in this second group of songs is immediately evident. Most of the Persian present in these texts is imagery and vocabulary that would be very familiar to dîvân readers. Again, the mix is held together by Turkish, which in the case of this second group of texts mostly provides verbs, but little more. The ezâfe is immediately detected, binding mostly Persian, but also Arabic words. The theme is, once again, the pangs of love and the excitement of flirtation and love drunkenness.

What do we make of the coexistence of such registers - the cohabitation of a classical, sophisticated tone with a more straightforward one to convey grief, love, innocence and light-hearted enjoyment? What do we make of this in the midst of discourses of authority versus accessibility, "unreadability" versus openness, simplification? Most importantly, what do we make of song channelling these strands? I believe the examples above show us that, according to the theme treated and the emotions intended to be 
conveyed, choices are made with regards to the language and the register. In particular, it seems to me that Persian is the choice when the beauty of the beloved (mehlikâ, a "beauty as fair as the moon"), the drunkenness that love subjects the loving heart to (dîde-i mestâne, "drunken eye") and the piercing pain that unattainable beauty and love provoke (feryâd, "cry for help," or a flourishing, ma'mûr - which is Arabic - heart that has been made virâne, or "in ruins" - and we are back to Persian) have to be conveyed (see Tietze and Lazard, 1967 for Persian loanwords in Turkish). One word caught my attention, in song 8, and it is nâr, the Arabic for "fire". The ezâfe compound is interesting here: the often found expression "fire of love" is here rendered by using the Arabic nâr as opposed to the Turkish word for fire, ateş (âteş is also found in Persian: another case of a word that has been appropriated to the point that it is considered Turkish; see above for âteş-i aşk). This particularity may appear insignificant. However, I believe that it is in these language choices that are operated on the basis of how much sophistication - or perhaps affection? - is required to express a certain concept, or describe a certain emotion, that we can find some answers. Nâr-i aşk and âteş-i aşk have the same meaning and they are held together by the same ezâfe structure. However, the "fire" is evoked by a Turkish-appropriated word in a song that narrates the most light-hearted aspect of love and merry-making while the Turkish-appropriated Arabic is used in a song that narrates the anguish of incurable love. The bîmar-ı aşk ("he who is ill with love", using both Persian - bîmar - and Arabic, aşk) finds no cure. Niçun bir çâre yok nâçâr-I aşka/Rehâ olmaz mı bend-i nâr-ı aşka: "why is there no cure for the one who is helpless for love/is there no escape for the slave of the fire of love?" The vocabulary, imagery and content would be known to the reader of dîvân. They are not particularly sophisticated or complex but they display choices and a linguistic architecture that reflects on-going affections and a familiarity for a common language and poetry repertoire. Most importantly, they are an example of language choice operated on the basis of occasion. This is not only related to the theme - light-heartedness versus hopelessness - that, after all, may very well be expressed in Turkish. Rather, what is noteworthy is that particular expressions to describe particular emotions are still solidly encased with the conventions and tradition of the dîvân, as references to modes of expression that, despite how problematic they were beginning to - and soon would become, still held an important place in the self-mapping within history of readers and interpreters of the texts. 
Returning to the idea of registers replicating relations, it will be helpful to reflect on the importance of developing a language for political, as well as poetic purposes, and what this reveals of those relations (see also Strauss, 2017). The poetic canon and language were, according to Carter Findley, developed in the court as part of a project to legitimise the imperial system as a whole (1980). An integral part of this project was the development of a language to fulfil the bureaucratic and literary aspirations - and needs - of an emerging power: Findley remarks that the texture of the language itself was impregnated with the Ottomans' sense of themselves and their place in the Islamic tradition (ibid.). It was a ruling class product, a Frankenstein bred in a rarefied space, the sarây. The edeb (translated by Findley as "good breeding", sophistication, good manners, refined education etc., 8) literary tradition came to be associated with the world of scribes and the palace school (Mekteb-i Enderûn or Enderûn-ı Hümâyûn). However, as we have already seen, this poetic tradition was not confined to the court. It existed beyond that rarefied space. The song-text taking that poetry across domains is one example. The juxtaposition of traditional formulas with their conventional meanings on a media space that proposed to re-adjust the linguistic domain they originated from is an example of that interdiscursivity and registers moving circularly across spheres of influence that Gal discusses. She rightly invites us to reflect not only on "how registers are made, but what is made with registers" (3) and poses enregisterment as an agent, and not simply as an exercise in demographics (5). She proceeds to show how register juxtaposition and borrowing/repetition across domains works in favour of specific political agendas and highlights particularly the sense of authority that register conveys and how that sense is manipulated to achieve political goals.

Authority as inherent to register, and register use is also discussed by Timo Kaartinen, looking at an Indonesian village chronicle. He highlights the way that song, among other types of oral and written texts, regulates community members' relations but also their positioning of themselves in their own history, amidst conflicts, disasters, colonialism etc. (2015). This partly resonates with the point made by Findley regarding the Ottomans locating themselves within the Islamic tradition via the development of language and a literary tradition. Kaartinen, citing Malcolm, defines register as "predictable conjuration of codal resources that members of a culture typically 
associate with a particular recurring communicative situation" (2015: 165). In the case of chronicles, "different types of formal language ... signify traditional authority and truth" (ibid.) and it is via registers that the speakers - and listeners - position themselves in speech and contexts of social engagement (ibid.). Linguistic registers, further observes Kaartinen, "are entangled with different registers of self-knowledge and truth" (2015: 166), thus signifying a process of self-discovery and in-context positioning. The songs used by Kende in his performances, in particular, have the function to bring to the listeners the voices of "ancestors of linguistic and ethnic others" (2015: 173), thus producing a map for the audience to move across, finding itself through the contrast with the others and their past. All of it, through recognizable and relatable register formulas. Kaartinen also highlights how song is synonymous with authority in that it is regarded as conveying the truth regarding events which are contested by different parties (2015: 175). The most important aspect of register use in narrative/poetic texts, however, are the relationships established between the readers and the text and the readers and the contexts those texts took shape from. Coming back to the Ottoman şarkl, the point is crucial in evaluating the agency of this song form in establishing and maintaining relationships between readers from middle and higher class backgrounds and the contested, classical heritage in transition towards modernity. That is, this vocal repertoire as it appears in this particular media, at this particular juncture is a means of self-discovery in relation to tradition as well as an opportunity to reflect on one's place within that tradition. Such relations are regulated through language in the space of the song-text and, most importantly, attachments and affections are revealed in the flourishing of the repertoire at a time in which the nature of its linguistic content and affiliations were intensely debated. What is revealed, is a fluid language framework in which an on-going relational negotiation occurs, and that should not be thought of in terms of a divide. A fluidity shared by the genre, that moves across social groups and linguistic registers thus both reflecting the debate but also resisting absolute categorisation. This aspect, were one to look closely, also characterizes the language learning and teaching methods, and the terminology used to indicate their contents. The fluidity should also be observed in the fact that the vocabulary used has transcended linguistic origin and acquired its own specific meanings and presence in the language that has fully adopted it. 


\section{Conclusion}

With this paper, I have tried to propose ways of thinking about song's role in subverting or supporting - or both - language policies and practice. By focusing on the late Ottoman şarkl, I have suggested that this art song form played a part in maintaining affections towards a shared linguistic and literary repertoire that was beginning to become controversial in the late 1800s, and would come to be seen as such during the Republic, with an increasing focus on the Turkish language and poetry/music forms. Furthermore, I discussed the song-text in relation to linguistic registers, arguing that the şarkı began, and continued to exist, in a form merging registers that reflects the reality of both newspaper language practice and methods used in language education. I have made my case against regarding what has been called "Ottoman Turkish" as a language far removed from Turkish as it is known and spoken nowadays, emphasizing how often the choice of terms depended on the content intended to be produced and how etymological origin is lost in communication, due to the appropriation of shared vocabulary.

My conclusions are as follows:

- The concept of linguistic registers and its use in song-lyrics can be helpful in reflecting on the ideology of song. Song carries its own ideological weight, subverting or supporting policy and ideology.

- The case of the Ottoman şarkı tells us that registers coexisted in song-text as much as in the press.

- These registers, in the context of both song and song published in press, may tell us of on-going affections and relations of the readers to their heritage, at a time of critical transformations.

- The texts proposed are an example of how the interweaving of registers worked in the şarkl, and the possible emotions the choice of vocabulary elicits/manifests.

- It is observed that a more straightforward Turkish text is linked to more lighthearted themes, while more elaborate use of Arabic and Persian is used for topics of greater emotional intensity. This may not be the general rule, however, it tells 
us something regarding the relationship between form and content, as manifested through language.

An in-depth linguistic analysis and response to my suggestions would undoubtedly enrich my proposition. It is one of my hopes that these ideas will generate a discussion that could be useful to both the fields of musicology and linguistics, and beneficial to further understanding the interaction of song with language practice.

\section{REFERENCES}

Akaslan, Yaşar. (2018). "Türkiye'de Kıraat İlmi Eğitim-Öğretimi." [The Education of Qur'ān Recitation (Qirā'āt) in Turkey]. Cumhuriyet İlahiyat Dergisi. 22(2): 1081-1107.

Akdoğu, Onur. (1995). Türk Müziği'nde Türler ve Biçimler [Types and Forms in Turkish Music]. İzmir: Can Ofset.

Aksoy, Bülent. (2003). Avrupalı Gezginlerin Gözüyle Osmanlılarda Musiki [Ottoman Music through the Eyes of European Travellers]. İstanbul: Pan Yayıncılık.

Ali Rıfat Bey. (1895). Hüsn-ı Güftarın Senin Ey Mehlikâ [Oh You, Beautiful as the Moon, the Beauty of Your Speech] [Musical Score and Lyrics]. Ma'lûmât. Aattürk Library Archive, İstanbul.

Andrews, Walter G. (1985). Poetry's Voice, Society's Song: Ottoman Lyric Poetry. Seattle and London: University of Washington Press.

Andrews, Walter G; Black, Najaat and Kalpakll, Mehmet (eds. and trans.) (2006). Ottoman Lyric Poetry: An Anthology. Seattle: University of Washington Press.

Ârif Bey. (1895). Deva Yok mu Neden Bimar-ı Aşka [Is There No Remedy, Why, to the Love-Sick?] [Musical Score and Lyrics]. Ma'lûmât. Atatürk Library Archive, İstanbul.

'Âsım, Necîb. (1893). Urâl ve Âltây Lisânları [Ural and Altaic Languages]. İstanbul: Kitâpçı Kasbâr. 
Bauman, Richard and Sherzer, Joel, ed. (1974). Explorations in the Ethnography of Speaking. Cambridge: Cambridge University Press.

Bauman, Richard. (2000). “Language, Identity, Performance.” Pragmatics. 10(1): 1-5.

Benes, Tuska. (2008). In Babel's Shadow: Language, Philology, and the Nation in Nineteenth-Century Germany. Detroit: Wayne State University Press.

Bergeron, Katherine. (2010). Voice Lessons: French Mélodie in the Belle Epoque. Oxford: Oxford University Press.

Bombaci, Alessio. (1956). Storia della letteratura turca: dall'impero di Mongolia all'odierna Turchia. [History of Turkish Literature: Since the Mongol Empire to Today's Turkey]. Milano: Nuova Accademia Editrice.

Cemîl, Mahmûd. (1893). Şevk-i Dil, Bahâriye Şarkı Mecmuası [Desire of the Heart, Springtime Song Collection] . İstânbûl: Matbaa-yı Safâ ve Enver.

Cemîl, Mahmûd. (1894). Şevk-i Dil, Bahâriye Şarkı Mecmuası [Desire of the Heart, Springtime Song Collection]. İstanbul: Âlem Matbaası - Ahmed İhsân ve Şürekâsı.

Civan Ağa. (1895). Ey Dil ne Oldun Feryât Edersin [Oh Heart, What Happened, You Cause Despair]. [Musical Score and Lyrics]. Ma'lûmât. Atatürk Library Archive, İstanbul.

Collins, James and Blot, Richard K. (2003). Literacy and Literacies: Texts, Power and Identity. Cambridge: Cambridge University Press.

Daskalov, Roumen; Marinov; Tchavdar. (2013). Entangled Histories of the Balkans. Volume One: National Ideologies and Language Policies. Leiden, Boston: Brill.

De Mauro, Tullio. (1991). Storia Linguistica dell'Italia Unita [Linguistic History of Unified Italy]. Roma, Bari: Editori Laterza

Duben, Alan; Behar, Cem. (1991). Istanbul Households: Marriage, Family and Fertility 1880-1940. Cambridge, New York, Port Chester, Melbourne, Sydney: Cambridge University Press.

Edwards, John. (2009). Language and Identity. Cambridge: Cambridge University Press. 
Ekinci, Mehmet Uğur. (2016). Kevserî Macmû'ası: 18. Yüzyıl Saz Müziği Külliyatı. [The Kesverî Collection: 18th Century Complete Instrumental Works] İstanbul: Pan Yayıncilık.

Emin Bey. (1895). Bir Gül-ı Ranâye Gönül Bağladım [I Am Attached to a Beautiful Rose] [Musical Score and Lyrics]. Ma'lûmât. Atatürk Library Archive, İstanbul.

Erdemir, Avni. (1999). Anadolu Sahası Musikişinas Divan Şairleri. [Divan Musician-Poets of the Anatolian Area] Ankara: Türk Sanatı ve Eğitimi Vakfı (TÜSAV) Yayınları: 1

Ertürk, Nergis. (2011). Grammatology and Literary Modernity in Turkey. New York: Oxford University Press.

Erol, Ayhan. (2012). "Music, Power and Symbolic Violence: the Turkish State's Music Policies During the Early Republican Period." European Journal of Cultural Studies. 15 (1): 35-52.

Feldman, Walter. (1990-1991). "Cultural Authority and Authenticity in the Turkish Repertoire." Asian Music. 22 (1): 73-111.

Feldman, Walter. (1996). Music of the Ottoman court. Berlin: Verlag für Wissenschaft und Bildung.

Ferahfezâ yâhûd Yeni Şarkı [Ferahfezâ or New Song]. (1896-1897). Atatürk Library Archive, İstanbul

Findley, Carter Vaughn. (1980). Bureaucratic Reform in the Ottoman Empire: The Sublime Porte, 1789-1922. Princeton: Princeton University Press.

Fortna, Benjamin. (2011). Learning to Read in the Late Ottoman Empire and the Early Turkish Republic. Basingstoke and New York: Palgrave Macmillan.

Frieson, Elizabeth B. (2000). "Cheap and Easy: the Creation of Consumer Culture in late Ottoman Society." In Consumption Studies and the History of the Ottoman Empire, 15501922: an Introduction, Ed. Donald Quataert: 243-260 New York: State University of New York Press. 
Frishkopf, Michael. (2013). “Against Ethnomusicology: Language Performance and the Social Impact of Ritual Performance in Islam." Performing Islam. 2(1): 11-43.

Frishkopf, Michael. (2018). "Paralinguistic Ramification of Language Performance in Islamic Ritual." Yale Journal of Music \& Religion. 4(1): 5-27.

Gal, Susan. (2011). "Polyglot Nationalism. Alternative Perspectives on Language in 19th Century Hungary." Langage et Société. 136: 31-54.

Gal, Susan. (2015). "Imperial Linguistics and Polyglot Nationalisms in Austria-Hungary: Hunfalvy, Gumplowicz and Schuchardt" Balkanistica. Eds. Donald L. Dyer, Brian A. Joseph and Christina E. Kramer. 28(1): 151-175.

Gal, Susan. (2018). "Registers in Circulation: the Social Organization of Interdiscursivity." Signs and Society. 6(1): 1-24.

Gökalp, Ziya. (2017). Türkçülüğün Esasları [The Principles of Turkism]. İstanbul: Kapı Yayınları. [Original work published in 1923].

Günaydın, Neva. (2018). “Türk Makam Müziği’nde Taksim ve Çalışma Yöntemi Olarak Şarkı Formunun Kullanımı." [The Use of the Şarkı Form as Taksim and Study Method in Turkish Makam Music]. Master Thesis, Istanbul Technical University, Istanbul: Turkey.

Hall, Leslie R. (1989). The Turkish fasil: selected repertoire. PhD thesis. University of Toronto.

Hakkı Bey. (1895). Tezyin Ediyor Gülşenî Şebboy ile Sünbül [The Wallflower and Hyacinth Adorn the Rose Garden] [Musical Score and Lyrics]. Ma'lûmât. Atatürk Library Archive, İstanbul.

Hâşim Bey. (1895). Mecbûr Oldum Ben bir Güle. [I Became Bound to a Rose] [Musical Score and Lyrics]. Ma'lûmât. Atatürk Library Archive, İstanbul.

Holbrook, Victoria Rowe. (1994). The Unreadable Shores of Love: Turkish Modernity and Mystic Romance. Austin: University of Texas Press. 
Hristo Efendi. (1895). Gidelim Göksu'ya bir Âlem-i Âb Eyleyelim. [Let's go to Göksu and Have a Drinking Party] [Musical Score and Lyrics]. Ma'lûmât. Atatürk Library Archive, İstanbul.

İz, Fahir. (1964). Eski Türk Edebiyatında Nesir. İstanbul: Osman Yalçın Matbaası

İz, Fahir and Menemencioğlu, Nermin (eds.) (1978). The Penguin book of Turkish verse. London: Penguin Books.

Kalender, Ruhi. (1978). “20. yy. Başlarında İstanbul’un Musiki Hayatı.” [The Musical Life of Istanbul in the Early 20th Century]. Musiki Dergisi. Retrieved from http://www.musikidergisi.net/?p=2258

Kaartinen, Timo. (2015). “The Registers and Persuasive Powers of an Indonesian Village Chronicle." In Registers of Communications. Eds. Asif Agha and Frog: pp. 165-186. Helsinki: Finnish Literature Society, SKS.

Kamusella, Tomasz. (2009). The Politics of Language and Nationalism in Modern Central Europe. Basingstoke and New York: Palgrave Macmillan.

Kanal, Hümmet. (2016). “Sultan II. Abdülhamid'in Osmanlı Eğitimine Yaptığı Önemli bir Katkı: Emlâk-ı Hümâyûn'a İnşa Edilen Okullar" [An Important Contribution of Sultan Abdulhamid II to Ottoman Education System: the Schools Built on Sultan's Land]. SUTAD 40: 151-176.

Kunt, Metin. (2008). "Reading Elite, Elite Reading." In Printing and Publishing in the Middle East. Ed. by Philip Sadgrove: pp. 89-99. Oxford: Oxford University Press.

Kushner, David. (1998). Türk Milliyetçiliğinin Doğuşu (1876-1908). [The Rise of Turkish Natioanalism (1876-1908)]. (Doğan, Zeki, Trans.). İstanbul: Fener Yayınları. [Original work published in 1977].

Levend, Agâh Sırrı. (1960). Türk Dilinde Gelişme ve Sadeleşme Evreleri. [Stages of Development and Simplification in the Turkish Language]. Ankara: Türk Tarihi Kurumu Lewis, Geoffrey. (1999). The Turkish Language Reform: a Catastrophic Success. Oxford: Oxford University Press. 
Mardin, Şerif. (2002). "Playing Games with Names." Fragments of Culture: The Everyday of Modern Turkey. Eds. Deniz Kandiyoti and Ayşe Saktanber: pp. 115-127. London, New York: I.B. Tauris \& Co Publishers.

Myhill, John. (2006). Language, Religion and National Identity in Europe and the Middle East: A Historical Study. Amsterdam, Philadelphia: John Benjamins Publishing Company

Nic Craith, Máiréad. (2007). Language, Power and Identity Politics. Basingstoke and New York: Palgrave Macmillan.

O’Connell, John Morgan. (2013). Alaturka: Style in Turkish Music. London and New York: Routledge.

Özalp, Mehmet Nazmi. (1992). Türk Musikisi Beste Formları. [Turkish Music Composition Forms]. Ankara: Milli Eğitim Bakanlığı.

Özbilen, N. Özgül; Ayangil, Ruhi. (2009). "Fasıl Şarkıcılığı Açısından Türk Makam Müziği'nde Süslemeler." [Ornamentation in Turkish Makam Music from the Perspective of Fasıl Singing]. Müzik Kültürü ve Eğitimi, Vol: II: pp. 565-572. Ankara: Atatürk Kültür, Dil ve tarih Kurumu. Retrieved from https://www.ayk.gov.tr/wpcontent/uploads/2015/01/\%c3\%96ZB\%c4\%b0LEN-N.-

\%c3\%96zg\%c3\%bcl\%e2\%80\%93AYANG\%c4\%b0L-Ruhi-FASIL-

\%c5\%9eARKICILI\%c4\%9eI-A\%c3\%87ISINDAN-T\%c3\%9cRK-MAKAMM\%c3\%9cZ\%c4\%b0\%c4\%9e\%c4\%b0\%e2\%80\%99NDE-S\%c3\%9cSLEMELER.pdf

Öztuna, Yılmaz. (1986). Hacı Ârif Bey. Ankara: Kültür ve Turizm Bakanlığı Yayınları

Öztuna, Yılmaz. (1988). Şevki Bey. Ankara: Kültür ve Turizm Bakanlığı Yayınları

Paçacı, Gönül. (2010). Osmanlı Müziğini Okumak. Neşriyât-ı Musikî. [Reading Ottoman Music. Music Publications]. İstanbul: T.C. Kültür ve Turizm Bakanlığı.

Poulos, Panagiotis C. (2014). “Özel Mekânlar, Kamusal İlgiler: İmparatorluk'tan Cumhuriyet'e İstanbul'da Müzikli Ev Toplantıları (Meclisleri)" [Private Places, Public Interests: Istanbul Musical House-Gatherings from the Empire to the Republic]. Toplumsal Tarih 242 (February): 82-89. 
Rizâ Efendi. (1895). Âh Düşeyim Der iken Eyvâh Vefâlısına. [Ah, When I Said Let Me Fall for Her Truthfulness] [Musical Score and Lyrics]. Ma'lûmât. Atatürk Library Archive, İstanbul.

Rizâ Efendi. (1895). Bak şu Güzel Köylüye İște bu Kızdır Peri [Look at this Beautiful Village Girl, Indeed a Fairy is this Girl] [Musical Score and Lyrics]. Ma'lûmât. Atatürk Library Archive, İstanbul.

Rizâ Efendi. (1895). Aman ey Yâr-ı Cefâ-pîșe Nizâr Etme Beni [Oh Cruel Beloved, Do Not Break Me Down] [Musical Score and Lyrics]. Ma'lûmât. Atatürk Library Archive, İstanbul.

Salgar, M. Fatih. (2011). Hacı Arif Bey: Hayatı, Sanatı, Eserleri. [Hacı Arif Bey: his Life, Art, Works]. İstanbul: Ötüken.

Salgar, M. Fatih. (2017). Türk Müziğinde Makamlar, Usuller ve Seyir Örnekleri. [Makam, Rhythmic Cycles and Development in Turkish Music]. İstanbul: Ötüken.

Signell, Karl. (1980). “Turkey’s Classical Music, a Class Symbol.” Asian Music. 12 (1): 164-169.

Somel, Selçuk Akşin. (2010). Osmanlı'da Eğitimin Modernleşmesi (1839-1908): İslâmlaşma, Otokrasi ve Disiplin. [The Modernization of Public Education in the Ottoman Empire (1839-1908): Islamization, Autocracy, and Discipline] (Yener, Osman, Trans.). İstanbul: İletişim publications, [Original work published 2001].

Spooner, Brian and William L. Hanaway, eds. (2012). Literacy in the Persianate World: Writing and the Social Order. Philadelphia: University of Pennsylvania Museum of Archaeology and Anthropology.

Stokes, Martin. (2010). The Republic of Love: Cultural Intimacy in Turkish Popular Music. Chicago: University of Chicago Press.

Strauss, Johann. (1995). "The Millets and the Ottoman Language: The Contribution of Ottoman Greeks to Ottoman Letters (19th-20th Centuries)." Die Welt des Islams, New Sources 35(2): 189-249. 
Strauss, Johann. (2017). “Language and Power in the Late Ottoman Empire.” In Imperial Lineages and Legacies in the Eastern Mediterranean: Recording the Imprint of Roman, Byzantine and Ottoman Rule. Ed. Rhoads Murphey: pp. 115-142. London and New York: Routledge.

Şahbaz, Namık Kemal. (2004). “Türkçe Öğretimi Açısından Elifba Kitapları.” [Alphabet Books with Regards to the Teaching of Turkish]. [Paper presented at İnönü University XIII. National Education Sciences Congress on July 6-9, 2004, Malatya, Turkey].

Retrieved from

https://www.academia.edu/909857/T\%C3\%9CRK\%C3\%87E_\%C3\%96\%C4\%9ERET \%C4\%B0M\%C4\%B0_A\%C3\%87ISINDAN_EL\%C4\%B0FBA_K\%C4\%B0TAPLARI

Tekelioğlu, Orhan. (1996). "The Rise of a Spontaneous Synthesis: the Historical Background of Turkish Popular Music." Middle Eastern Studies. 32 (2): 194-215.

Tietze, Andreas and Lazard, Gilbert. (1967). "Persian Loanwords in Anatolian Turkish." Oriens. 20: 125-168.

Tohumcu, Ahmed. (2009). “Türk Müziği Terminolojisinde Yozlaşma - Örnek Olay Analizi: Şarkı Formu." [The Degeneration in Turkish Music Terminology - Case Study Analysis: the Şarkı Form]. Müzik Kültürü ve Eğitimi, II. Cilt: pp. 711-718. Ankara: Atatürk Kültür, Dil ve tarih Kurumu. Retrieved from https://www.ayk.gov.tr/wpcontent/uploads/2015/01/M\%c3\%9cZ\%c4\%b0K-K\%c3\%9cLT\%c3\%9cR\%c3\%9c-VEE\%c4\%9e\%c4\%b0T\%c4\%b0M\%c4\%b0-2.-C\%c4\%b0LT.pdf

Toker, Hikmet. (2016). Elhân-ı Aziz: Sultan Abdülaziz Devrinde Sarayda Mûsikî. [Melodies of Aziz: Music in the Court in the Era of Sultan Abdülaziz]. Ankara: TBMM Milli Saraylar.

Topuzkanamış, Ersoy. (2018). “Osmanlı Dönemi İlk Modern İptidaiye ve Rüştiye Programlarında Türkçe Eğitimi: 1891 Yılı Örneği." [Turkish Education in the First Modern Elementary and Secondary School Curricula of the Ottoman Period: The Sample of Year 1891] OTAM 43: 247-280

Twine, Nanette. "Script Reform Movements in the Meji Period." Monumenta Nipponica 38, no. 2 (1983): 115-132. 
Uzun, Mustafa and Özkan, İsmail Hakkı. (2010). "Şarkı". [Şarkı Song] İslâm Ansiklopedisi, Retrieved from https://islamansiklopedisi.org.tr/sarki--musiki\#2-musiki Ünlü, Cemal. (2016). Git Zaman, Gel Zaman. Fonograf, Gramofon, Taş Plak. [As the Time Goes By. Phonograph, Gramophone, Record]. 2nd ed. İstanbul: Pan Yayıncılık.

Vurgun, Ahmet. (2017). II. Abdülhamid Dönemi İlköğretimde Ahlak Eğitimi. [Moral Education in Primary Education in the Time of Abdülhamid II.]. İstanbul: Yeditepe Yayınevi.

Woodhead, Christine. (2011). "Ottoman Languages.” The Ottoman World. Ed. Christine Woodhead: pp. 143-158. Hoboken: Routledge.

Yahya Kaçar, Gülçin. (2012). Klâsik Türk Mûsikisi Güftelerinde Osmanlıca Kelime ve Terkîbler. [Ottoman Words and Compounds in the Lyrics of Classical Turkish Music]. Ankara: Maya Akademi.

Yalçın, Gökhan. (2016). Hâşim Bey Mecmû'ası: Birinci Bölüm. Edvâr. [Hâşim Bey's Collection: First Volume. Circles]. Ankara: Atatürk Kültür Merkezi Başkanlığı.

Yenî Şarkılar, Yeni ve Nâdîde Şarkılar Hâvîdir (1896-1897) [New Songs, Containing New and Rare Songs]. Atatürk Library Archive, İstanbul.

Zeren Enis, Ayșe. (2013). Everyday Lives of Ottoman Muslim Women: Hanimlara Mahsus Gazete [Newspaper for Ladies (1895-1908)]. İstanbul: Libra Kitapçılık ve Yayıncılık. 